\title{
TWELVE MONTHS EXPERIENCE WITH A FIELD SURGICAL UNIT IN ITALY, 1944 - 1945
}

\author{
Major H. D. S. VELLACOTT, F.R.C.S., R.A.M.C. (Retd.)
}

SUMMARY: The trauma caused by modern traffic accidents and civil disorders, with explosions, missile injuries and burns, and the present day interest in accident services caused me to review my experience with a Field Surgical Unit in Italy in the year 1944-45, for many lessons learnt in wartime tend to be forgotten or are not sufficiently propagated in peace-time.

An attempt has been made to bring the review up-to-date from further experience and by reference to the literature.

My adventures were very minor compared with the ordeals suffered by fighting troops, and the experience relatively trivial in terms of the whole complex medical organisation involved, yet that experience provided a basic knowledge and interest which I like to think proved invaluable.

\section{Introduction}

A Field Surgical Unit (F.S.U.), nowadays better called a Field Surgical Team, consisted of a surgeon and anaesthetist, five medical orderlies and three drivers. One medical orderly was a theatre-trained Corporal (a Sergeant today) and another was a Lance-Corporal able to type, a most important asset. For transport we had two three-ton lorries and a 15 cwt. truck in which we carried an operating table, instruments, drums and sterile dressings, our own lighting equipment with a $1 \frac{1}{2}$ kilowatt generator in addition to our own personal equipment and tent accommodation.

We were parasitic for pay, food and drink, and depended on a host unit for beds for the wounded, nursing equipment and services.

\section{The role of a Field Surgical Unit}

Situated near the front line was a Regimental Aid Post (R.A.P.) with a medical officer, and stretcher bearers not R.A.M.C. personnel but trained in first aid. The Advanced and Main Dressing Stations of a Field Ambulance, staffed by R.A.M.C. personnel, usually lay just behind this region and next on the line of evacuation of casualties.

A F.S.U. might be attached at this level, or at a Field Dressing Station (F.D.S.) which had beds for 40 casualties, or a Casualty Clearing Station (C.C.S.) which had its own surgical team and commonly 200 beds.

There were no X-ray facilities ahead of the C.C.S. level.

Base hospitals lay at variable distances further back, depending on the particular logistics of the fighting. Special units such as neurosurgical, facio-maxillary, thoracic and orthopaedic might be attached at various levels, and in more recent warfare as in Korea and Viet-Nam, surgical teams came well forward when fighting became rather static.

A most important pre-requisite for any successful and efficient accident service is the classification and early separation of patients according to priorities. This is usually done at the Advanced Dressing Station of a Field Ambulance and today involves selection of patients for evacuation by helicopter (Field Surgery Pocket Book 1962).

\footnotetext{
* This was a paper read at the Plymouth Medical Society as a Presidential Address on 27 November 1970.
} 
No. 2 F.S.U. had been formed in the desert in November 1941 by Ian Aird, with Charles Murphy as Assistant-Surgeon and Brian Bamford as Anaesthetist (McLeave 1964). Aird had used what he called the Pent-House operating theatre with canvas draped over poles extending backwards from a truck. This had been abandoned for something more sophisticated when I joined.

When we had to, we used a so-called I.P.P. (Indian Pattern, Privates) tent (Fig. 1).

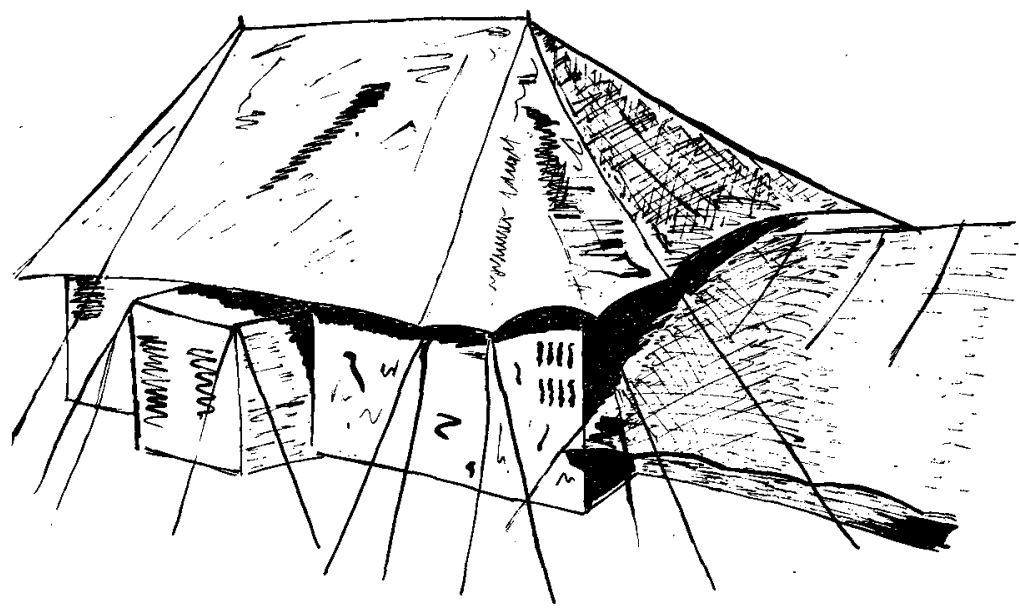

Fig. 1. Operating theatre tent.

This had a double canvas door arrangement and a transverse screen just inside to keep out wind, rain and dust. Another small tent was attached in which we arranged the sterile drums, the steriliser, and the means for "brewing-up". Surgical drums were sent off packed periodically to a Field Steriliser, which looked for all the world like a "Puffing Billy".

Bamford was justifiably proud of this little unit in which he played such a large part. Among other things, he had designed a very good lighting system with some dozen or more bulbs mounted on an overhead wooden trellis (Fig. 2). We also had a good spot-light.

\section{Military situation in Italy, May 1944}

The military situation in May 1944 was that the Germans had held for many months the so-called Gustav Line. Cassino, where there had been bitter fighting, barred the way to Highway 6 and Rome. The Anzio landing had been made on 22 February 1944 , but the bridgehead established had been contained by prompt German reaction.

No. 2 F.S.U. was attached to No. 1 C.C.S. at Lanciano in May 1944. The C.C.S. with its own surgical team, a Blood Transfusion Unit, a Canadian Research Team and an Italian Surgical Team, were housed in large buildings by the War Memorial at the West end of the town directly facing the Appenines (Fig. 3). We were all part of the 4th Indian Division.

German troops were in Orsogna opposite and in the foothills. Two battalions of one of the finest Italian regiments were in this sector, one fighting with us, the other with the Germans just opposite. The Italian Surgical Team was there mainly to deal 


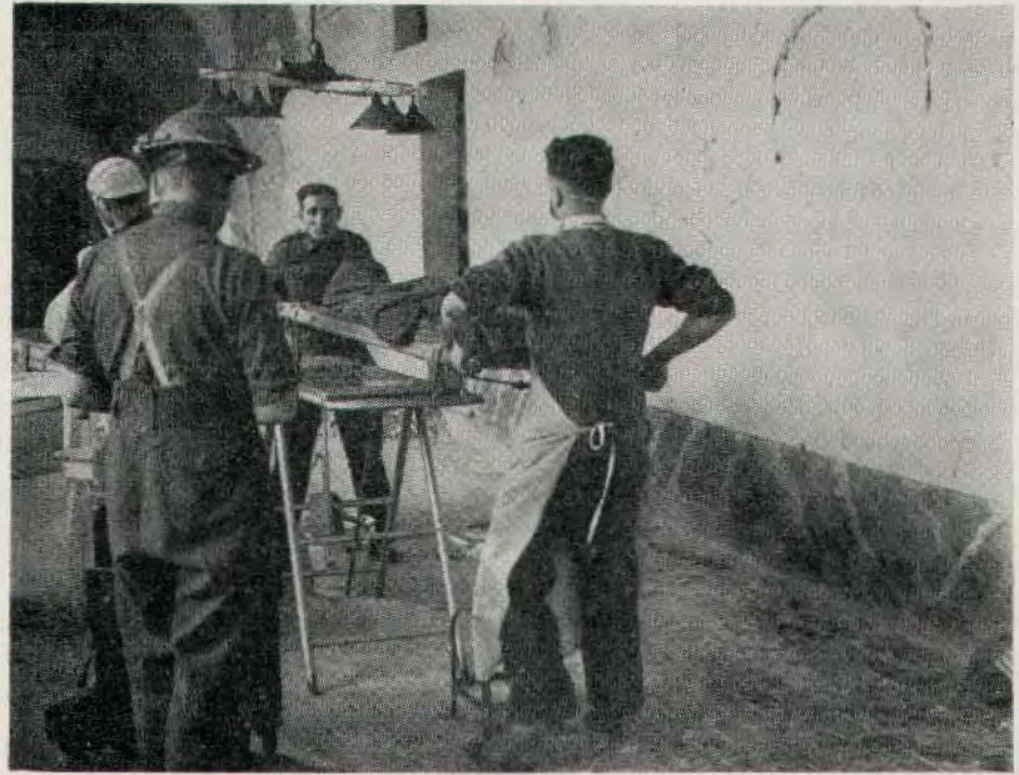

Fig. 2. Mobile surgery in the field. The lighting, mounted on a trellis, could be improved by adding more fittings and bulbs.

(Photograph by courtesy of the Impierial War Museum)

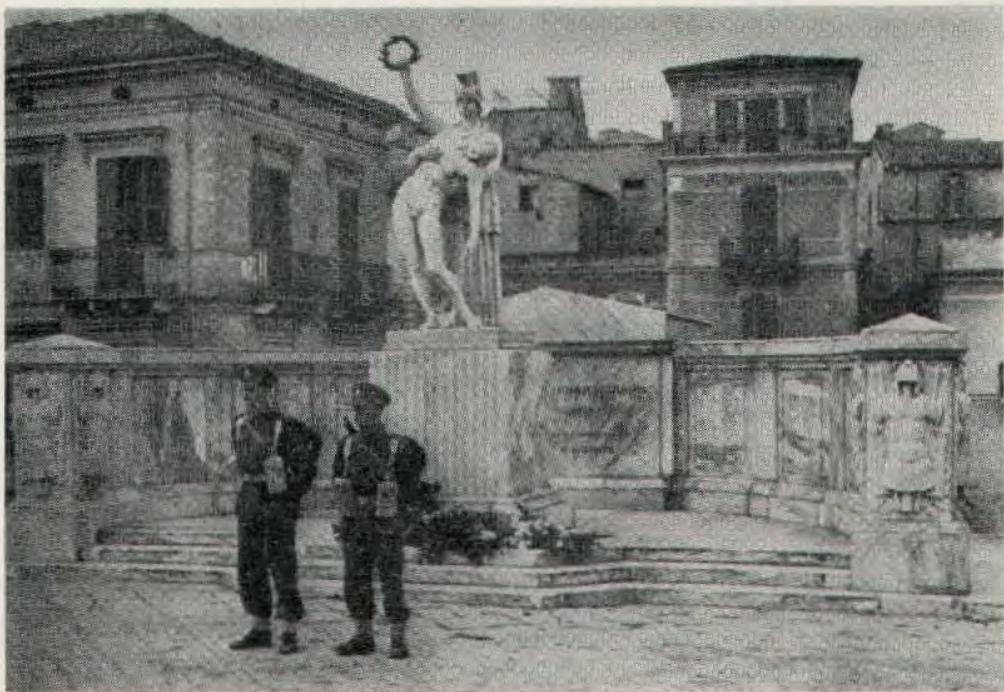

Fig. 3. Buildings occupied by No. 1 C.C.S. at Lanciano.

(Photograph by courtesy of the Imperial War Museum)

with the casualties from these regiments and with some from the civilian population.

The Germans showed great respect for the large red crosses painted round our building, and when one of our field batteries parked in the surrounding grounds, abusing the privileged protection which we enjoyed, it was quickly asked to move elservhere, and did so.

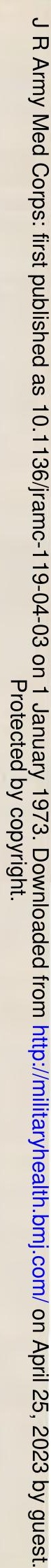


Sometimes the C.C.S. seemed to be used by the enemy gunners for ranging on. When I was fast asleep one morning, a shell air-burst immediately over us, giving a most unpleasant feeling of being driven into the ground. The crossroads in the middle of the town were shelled shortly afterwards.

On the 3rd May, the day after my arrival, I dived into field surgery at the deep-end to deal with three gunners severely wounded by enemy high-explosive shell fire. The blood transfusion officer had difficulty in getting one of these gunners fit for operation. He was suffering from multiple wounds, one penetrating the abdomen and causing multiple injuries to the bowel. One gunner, however, had a single large wound of the thigh and serves well as an example of the treatment of uncomplicated wounds.

After appropriate resuscitation, most clothing, often terribly soiled, would have been removed before admission to the theatre. Any remaining clothing was removed in the theatre and the skin of the limb was cleaned with soap and water and the whole limb shaved, while the wound was protected with a dressing. Then an antiseptic lotion was wiped over.

Skin is extremely valuable and should be conserved if apparently viable. The edges of the wound were therefore sparingly excised or trimmed around the entry wound over the lateral aspect of the thigh, and this wound extended to expose the underlying penetrated and contused fascia. Damaged fascia was excised and split further in a longitudinal direction and when necessary laterally. The muscle which appeared dull, did not respond to pinching and did not bleed when cut, was removed.

A haematoma over the other side of the thigh was incised and evacuated, and more injured muscle with a jagged metal foreign body, was removed. More important, there was often clothing and all sorts of debris which it was essential to remove. Adequate haemostasis was achieved.

The policy was not to close such wounds, but to aim at what was called 'delayed primary suture' about four days later. Penicillin and Sulphonamide powder was insufflated at this first operation, vaseline gauze, dry dressing and wool applied, the dressings being made absolutely secure. Although speed was desirable for obvious reasons, it was most important not to sacrifice proper care. The value of operative measures was lost if dressings were carelessly applied so that they came off in transit when the patient was evacuated for definitive care. When no fractures were present these dressings were secured by careful application of adhesive strapping.

The limbs with fractures were placed in padded Plaster of Paris. We carried a long piece of malleable metal which was placed under these plasters so that they could be split by a knife and the metal strip removed. Thomas's splints were used freely, and the Tobruk plaster was invaluable. The treated limb, usually fixed by skin traction on the Thomas's splint was simply encircled in a light covering of padded Plaster of Paris.

If one drew the underlying injury on the overlying plaster fairly accurately, surgeons at Base hospital sometimes would operate through a window in the Tobruk plaster, and I have had many follow-up cards recording that this was just what they did.

Damage to major vessels involved ligation of these vessels. There was little or no place for reconstructive arterial surgery. In Korea and Viet-Nam some specialised units dealt with such surgery, but much depends on the type of warfare and other circumstances. 
The R.A.M.C. scheme (Field Surgery Pocket Book 1962) is extremely flexible. A special unit may come forward to be attached with other surgeons at Field Ambulance, F.D.S., or C.C.S. level, or casualties may be evacuated after first aid treatment to a Base hospital, depending on the logistics of the fighting. Watts (1960) found little place for reconstructive surgery in Cyprus, commenting that the contusion of vessels practically rules this out. In Aden, Brown and Binns (1970) practised very occasional arterial suturing, but patients needing vein grafts were flown to the United Kingdom.

In Italy amputation had sometimes to be performed when the residual blood supply to the limb seemed insufficient, more especially when there was gross muscle damage with established or likely gas gangrene, or great disorganisation of a major joint in association with imperilled blood supply. Since those days there has been much research on missile injuries and much more experience (Peidelievre and Michon 1956, Hopkinson and Watts 1963, Thoresby and Watts 1967). High velocity missiles damage only tissue which they strike directly.

The basic principles of wound toilet have not altered since those times as has been emphasized by various authors writing of their experience in Korea, Cyprus, Aden and Viet-Nam.

\section{The Gustav Line}

The Torre Dam, 12 miles South-West of Chieti and 20 miles from Ortona, was dive-bombed on the 5th May, destroying its hydro-electric works and the local electricity supply and flooding Pescara and the German Lines (Fig. 4). The enemy withdrew

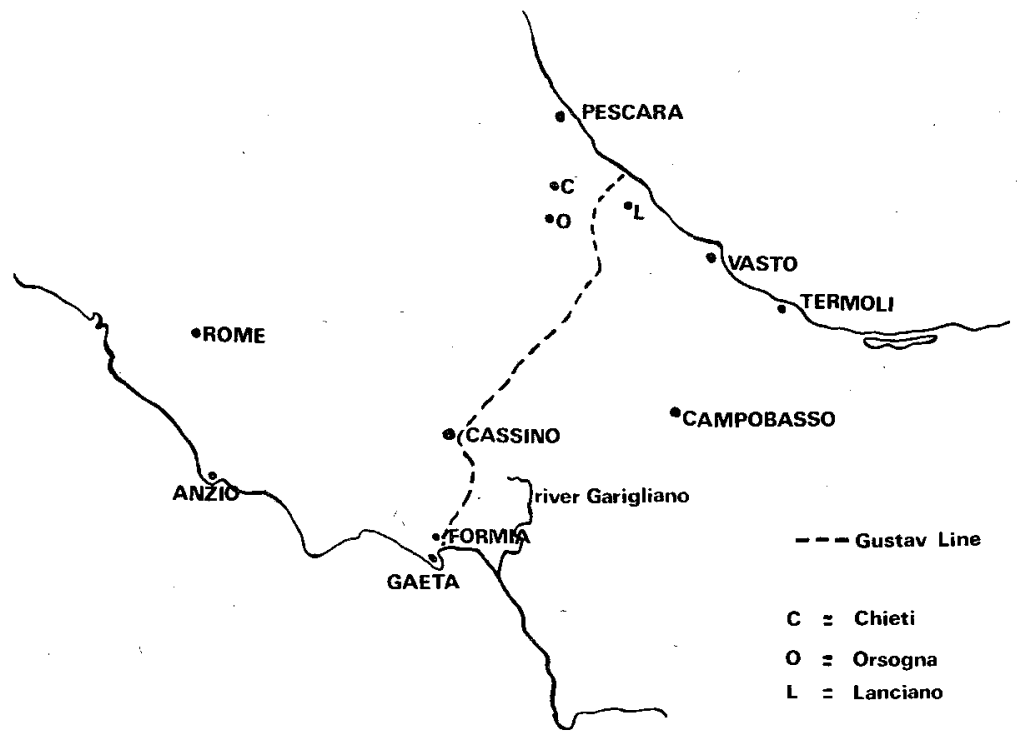

Fig. 4. The Gustav Line in 1944.

slightly in the next 48 hours and the 8th Army positions were pushed forward to the slopes of Monte Maielle, near Chieti.

By the 11th May the 8th Army had completed secretly switching its main forces, which it had been doing over the previous 8 weeks, from the Adriatic sector to Cassino, 
and at 11.00 p.m. that night the bombardment of the Gustav line commenced. Watching it from the roof of the C.C.S. there was a line of flashes and flames stretching right across Italy as far as the eye could see. The bombardment lasted 40 minutes and was greater than that at El Alamein. This began the battle to get into the Lire Valley behind Cassino.

Cassino fell after terrible fighting on the 17th May and on the 23rd the Anzio offensive began, culminating with the link up of the beach head and the main lines on the 25th May. On the night of 4th/5th June the American 5th Army occupied Rome, and at home the Second Front opened on the 6th June.

There was a general advance from the Tyrrhenian to the Adriatic sector on the 9th June, with the enemy retreating faster on the Adriatic side than was expected, and Indian troops occupied Pescara on the 10th June.

At Pescara I saw one of the worst and most rapid cases of gas gangrene encountered. A Sepoy wounded at 1000 hours on 13 June 1944 was admitted to the Main Dressing Station to which we were attached at 22-35 hours, some 12 hours later. He had a frozen right hand, absent radial pulse, elbow joint contracture to 45 degrees and a compound grossly comminuted fracture of the upper third of his humerus with multiple wounds around the shoulder joint. The characteristic odour of gas gangrene was quite apparent. There were other wounds involving his left upper limb, both thighs and right knee joint, and not surprising he was comatose. He died about 24 hours after a modified inter-scapulo-thoracic amputation and treatment of his other wounds.

Within a few days we were ordered back to Campobasso, and from there we moved forward, passing through Cassino on the way.

\section{The Gothic Line}

Some of the bitterest fighting in Italy occurred as the Germans formed into the Gothic Line from Pisa through Florence to Rimini, and by the 6th July much stronger resistance was met along the whole front. There was fierce fighting in the Arezzo region at this time.

We joined No. 52 F.D.S. just south of Arezzo on the 12th July, and apart from a period of 3 days we were attached to this unit until 2 October 1944, while it moved forward working in various areas. At Foiano Della Chiana we started operating in quite a fine building, which may have been a school, at eleven in the morning and worked through until the early hours of the next morning. A Regimental Officer with a compound fracture of the femur, who had been a General Duty Officer at 95 General Hospital in Algiers with me while I was on probation for grading as a surgeon, was one of the last patients we dealt with that night. I still treasure a letter from him when he made a good recovery.

\section{Bucine}

Bucine is in a little bend of the River Arno, practically parallel with Arezzo, and we worked here some very long hours. At times meals were brought to us in our tented theatre. After one particularly long spell I woke up after 12 hours to find the whole unit packed and ready to move again.

I never ceased to marvel at the work done by the Blood Transfusion Officers on these occasions. The nursing sisters also worked incredible hours, as did the medical officers. 
Penetrating wounds of the abdomen have always been a problem of warfare. Just two examples serve to stress that one of the biggest problems is that the abdominal wound is seldom the only one.

Early transfer to a centre capable of suitable resuscitation and surgery is the ideal. The assessment of these patients is based on fundamental surgical principles, with attention particularly to the type of weapon and the position of the wound at the time of injury, the physical signs to be found and the information obtained from X-rays.

One should assume that wounds are multiple as shown by 2 Cases (Tables I, II and Fig. 5), and deliberately search for wounds other than the obvious. One of the two

Table I

Case history

\begin{tabular}{|c|c|c|c|c|}
\hline Missile & Delay & Abdomen & Other wounds & Remarks \\
\hline $\begin{array}{l}\text { S.W. (H.E.) } \\
\text { on } \\
27 \text { July } 1944\end{array}$ & 26 hours & $\begin{array}{l}\text { Wound of R.I.F. } \\
\text { excised } \\
3 \text { perforations } \\
\text { in caecum } \\
\text { exteriorised }\end{array}$ & $\begin{array}{l}\text { 1- Compound fracture } \\
\text { 7th cervical } \\
\text { vertebra } \\
\text { 2- Left biceps } \\
\text { 3- Right scapula } \\
\text { sucking wound } \\
\text { of chest }\end{array}$ & $\begin{array}{l}\text { Hacmoptysis- } \\
\text { Died } 28 \text { July } 1944 \\
\text { Autopsy -Spinal } \\
\text { medulla intact. } \\
\text { Right lung collapsed. } \\
\text { due to missile. } \\
\text { Blast injury to } \\
\text { left lung. }\end{array}$ \\
\hline
\end{tabular}

Table II

Case history

\begin{tabular}{|c|c|c|c|c|}
\hline Missile & Delay & Abdomen & Other wounds & Remarks \\
\hline Grenade & 12 hours & $\begin{array}{l}\text { Spatter wounds } \\
\text { L.I.F. excised } \\
\text { Trunk and torso } \\
\text { wound: small } \\
\text { intestine closed }\end{array}$ & $\begin{array}{l}\text { 1- Compound depressed } \\
\text { front skull } \\
\text { 2- Left face } \\
\text { 3- Left chest } \\
\text { 4- Left upper limb } \\
\text { with fracture of } \\
\text { radius and ulna. } \\
\text { 5- Multiple right } \\
\text { thigh } \\
\text { 6-Multiple left } \\
\text { thigh }\end{array}$ & $\begin{array}{l}\text { Evacuated } \\
\text { Follow-up case } \\
\text { card "uneventful } \\
\text { recovery" }\end{array}$ \\
\hline
\end{tabular}

patients died, the other survived and Fig. 5 is the follow-up card returned for this patient.

Sixty-six penetrating wounds of the abdomen and thoraco-abdominal wounds were treated, consisting of 44 penetrating wounds of the abdomen -15 died, and 22 penetrating thoraco-abdominal wounds-10 died. Table III lists the viscera and organs injured in these patients, and the number of injuries to major intra-abdominal vessels found at operation were (a) One left common iliac vein. (b) One left common iliac artery, and (c) One inferior vena cava.

The number of wounded treated is relatively small, but the results are comparable with those obtained by others (War Surgery, Supplement No. 3, British Journal of Surgery). 


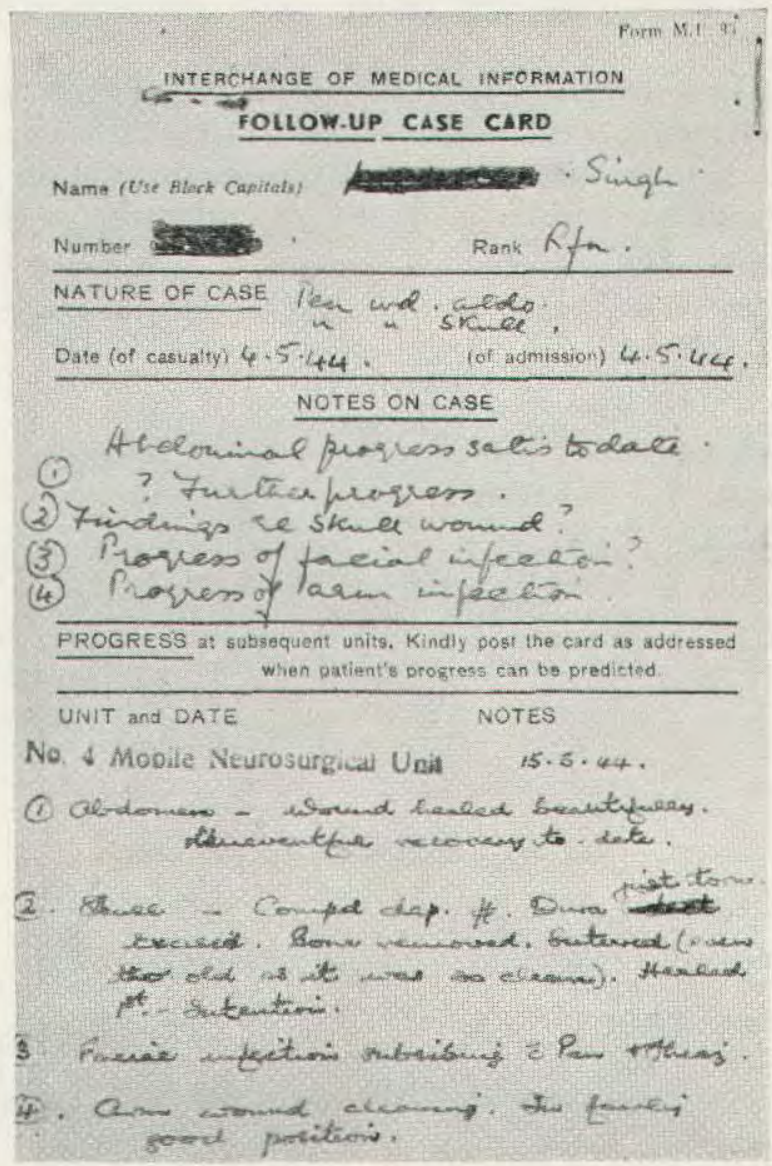

Fig. 5, Follow-up card of patient with multiple wounds.

Table III

Injured organs and viscera

\begin{tabular}{l|c|c|l|c|c}
\hline \multicolumn{1}{c|}{ Organ } & Abdominal & $\begin{array}{c}\text { Thoraco- } \\
\text { abdominal }\end{array}$ & \multicolumn{1}{c|}{ Organ } & Abdominal & $\begin{array}{c}\text { Thoraco- } \\
\text { abdominal }\end{array}$ \\
\cline { 2 - 6 } & 1 & 5 & Bladder & 10 & - \\
\hline Stomach & $20^{*}$ & 3 & Liver & 1 & 11 \\
\hline Large bowel & 12 & 4 & Pancreas & 1 & - \\
\hline Rectosigmoid & 1 & - & Spleen & - & 6 \\
\hline Rectum & 10 & - & Omentum only & 1 & - \\
\hline Kidney & - & 5 & No damage & 1 & - \\
\hline Ureter & 1 & - & & & \\
\hline
\end{tabular}




\section{Figline}

At Figline we worked in a very large building in pleasant grounds, but slept in tents. One of my most vivid recollections about Figline is of a goose called 'Donald ' which Dr. Michael Sutton's Blood Transfusion Unit took with it wherever it went, and this animal ruled the roost around his lorry.

\section{Salceto}

At Salceto, just south of Florence, we were in tents on the side of a hill. A narrow, dried-up river crossed the middle of the field and our theatre tent was sited above this without personal tents below. A German aircraft dived towards us one day here, but at the last moment he apparently saw our large red cross and pulled away. Shortly afterwards we dealt with a casualty who had been wounded in a tank when this aircraft came up behind the column. I mention this episode as we now had air superiority and rarely saw enemy planes.

During a heavy storm at night, a tree fell across the river bed which flooded its bank, so that water cascaded down the hill straight through the nursing sisters' tents. Their belongings and niceties of clothing floated down the side of the hill, but in spite of the torrential rain there was no lack of willing assistance as they ran around in very little but excitement.

One September evening I managed to sneak forward in the $15 \mathrm{cwt}$. truck to the Piazzale Michelangelo and gaze across the river Arno at the beautiful city of Florence. Somewhere on my left our guns were firing at the Germans in the foothills behind Florence. The statue of Boy David beside me had lost an important organ, probably carried away by a bullet. Although Florence had been declared an open city, all the bridges had been blown except the Ponte Vecchio. Years later, when I visited Florence again, I found that Boy David's manhood had been restored.

A Major with a penetrating left chest wound was admitted at Salceto; he was pale, sweating and very ill. The skin was only trimmed around the entry wound; the wound slightly enlarged, and muscle closed over a sucking area. The chest was aspirated repeatedly and a follow-up card which was returned later told us of his good recovery.

Out of a total of 34 penetrating wounds of the chest there were 5 deaths. We tended to be very conservative in treatment. Tiny penetrating wounds were left untouched, but many wounds with emphysema or fractured ribs were excised and a haemothorax was aspirated. Sucking wounds were closed, but reviewing the cases I am very much aware that we probably should have inserted more intercostal drains with underwater seals. The problem was that we were afraid of inserting drains for fear that rapid re-expansion of a collapsed lung might cause bleeding, and also the uncertainty of close control of the management of patients post-operatively whenever our unit might be moved suddenly, or the patient might have been evacuated. There are now modern devices, intra-pleural drainage catheters and drainage bags which are not as vulnerable as glass. Some points about penetrating wounds of the chest are shown in Fig 6 . The general policy, after excising wounds if necessary, was to get the chest closed, aspirate as necessary, and if other wounds allowed, get the patient back to a chest unit as quickly as possible, sometimes by air. Follow-up cards from the chest unit were among the best completed and some of the most interesting.

The emphasis was changed as best described by Edward D. Churchill, Surgical Consultant to the United States Army, Mediterranean Theatre, 1944:- 


\section{FIRST AID ENSURE AIRWAY \& RESPIRATION}

\section{Haemorrhage \\ Sucking
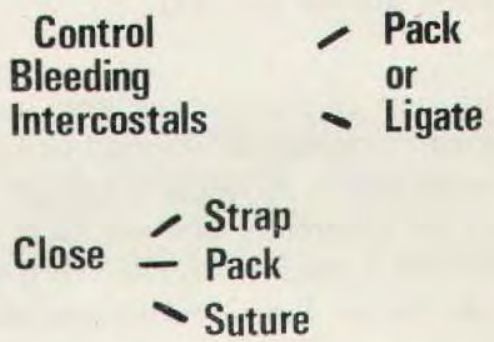 \\ Tension Pneumothorax Intercostal Catheter}

Fig. 6. Some points about penetrating wounds of the chest.

"The point of view that holds a chest injury to be progressing satisfactorily as long as pleural infection has not developed is no longer tenable. Every consideration is now given to the restoration of full lung function. The change of focus of attention from the pleural space to the lung stands as one of the most important achievements of the military surgeons in this war." (Edwards, H. C. 1945).

Today underwater seal drainage is adopted much earlier. One should also deliberately consider the possibility of injury to the other lung with perhaps the need for bilateral drainage and sometimes tracheostomy, but having said that, circumstances will often dictate what is possible.

The weather was very pleasant in the Florence area, and when the Germans withdrew into the mountains north of the city we had an opportunity to visit the city properly (Fig. 7).

Two tragedies which occurred at Rufina made a lasting impression on me. A soldier was brought in in a maniac condition requiring some six other people to hold him down. The tiniest trace of Pentothal was given intravenously to help control him, but he relapsed into a coma from which he never recovered. At autopsy the next day, he was found to have advanced cirrhosis of the liver.

A german prisoner of war came in with relatively minor wounds sustained quite a long time beforehand, a fact that we did not appreciate at the time. While his wounds were being excised he went into cardiac arrest and died in spite of open cardiac massage. I think he was a great deal more exhausted than we realised.

\section{Conaile}

We moved into the mountains in late September to join No. 1 Field Ambulance, where we occupied rough village buildings and experienced some torrential rain. German aircraft bombed the valley at nights. We started operating at $3.20 \mathrm{a} . \mathrm{m}$. on the morning of 5 October 1944.

At 11-45 that morning a Scots Guardsman was wounded by high explosive shell fire. A tourniquet was applied above a wound involving a knee joint, a back splint was 


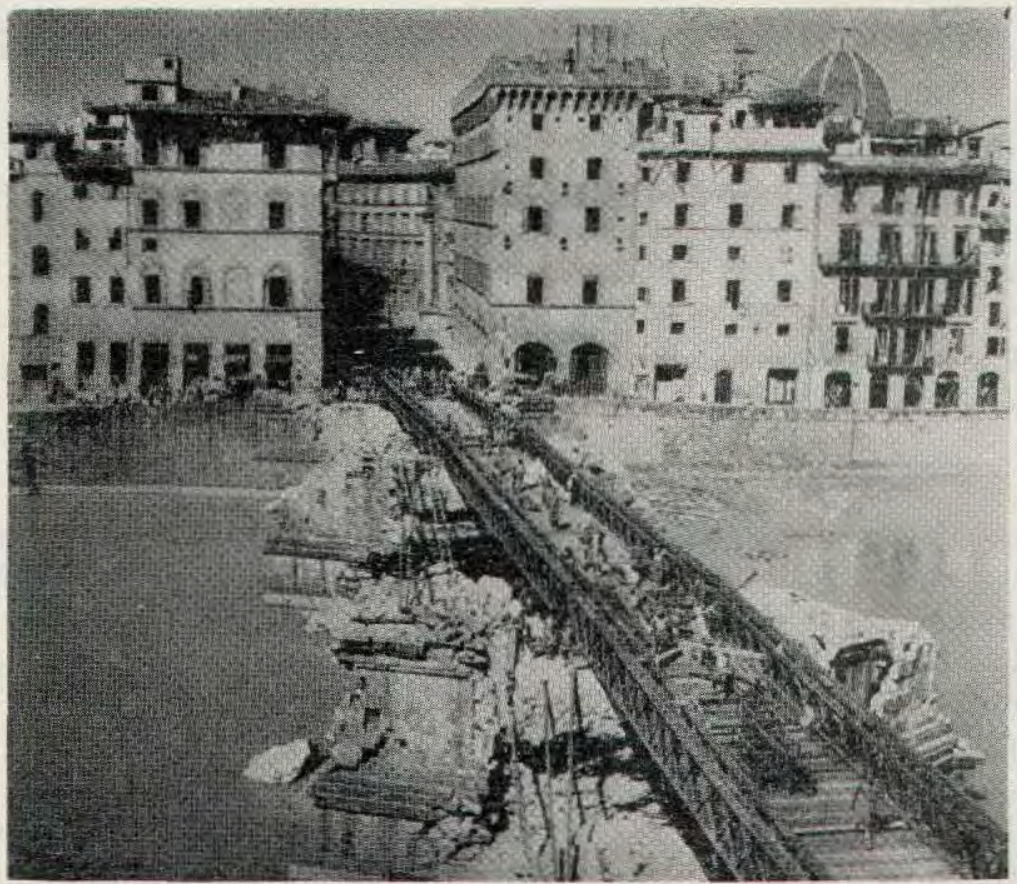

Fig. 7. View of Florence from the Ponte San Trinita. (Photograph by courtesy of the Imperial War Museum)

applied, and $\frac{1}{4}$ grain of morphia was given apparently within 5 minutes. He was handstretcher carried probably half a mile and then taken $1 \frac{1}{2}$ miles by Jeep to a mountain road. There an ambulance took him another 8 miles. He arrived at our Main Dressing Station at 1.30 p.m. apparently moribund. Gasping respirations occurred, one or two per minute. He was cold and white. Very slow, regular heart sounds were just audible at the apex, and he was unconscious. The foot of the stretcher was raised. One pint of blood was run in fast and oxygen was given by mask, with almost immediate dramatic response.

We then ran out of blood for transfusion, the only occasion I ever knew this to happen. We were comparatively isolated and I think that surgery had only just been commenced with this Field Ambulance. Intravenous plasma was started, but as our nearest British Unit was miles away down the mountains and there was an American Field Hospital only a mile or two away, a Dispatch Rider was sent hurtling down the mountain road to the American Unit. He asked for 5 pints of blood, was given it with no questions asked and was back with us in about 20 minutes.

By 3.00 p.m. the Guardsman had had 2 pints of plasma and 3 pints of blood, was a fair colour, with a blood pressure of $105 / 50 \mathrm{~mm}$, and was beginning to stir. Pulsation was present in the femoral artery below the tourniquet on the thigh, so this was removed and the leg redressed with firm bandage over wool, controlling the bleeding. Anterior and Posterior tibial pulses remained absent.

By 3.15 p.m. he was conscious and restless and during the next hour we debated between cases upon which we had to operate, whether we should operate upon him 
about this time, as his blood pressure rose to $115 / 75 \mathrm{~mm}$ and he became alert and joked with us as we attended him.

Unfortunately his blood pressure then began to fall steadily and although he had 5 pints of plasma and 5 pints of blood, he died. At autopsy he had a severed popiteal artery and a gross compound comminuted fracture of the femoral condyles into a completely disorganised knee joint, but nothing else to account for his death.

On the 31st October we joined No. 165 Light Field Ambulance at San Bennedetto en Alpe. The Main Dressing Station was in front of the Advance Dressing Station, and conditions were primitive. The village was in a narrow valley by a small river, and it rained incessantly. Briant Evans, whose F.S.U. was stationed at San Benedetto just before us wrote:-

"The Germans were some 3 miles up the road, beyond a damaged bridge which our Sappers constantly repaired only to have it knocked down by the German guns. It was a most uncomfortable spot. There were three batteries of medium guns on a small plateau just above, which fired intermittently all the time, bringing showers of plaster down off the ceiling and making it difficult to sleep."

We then returned to Scarperia and worked with No. 8 C.C.S. alongside the Shock Research Team (Grant and Reeve) until we returned to Conaile in the mountains with No. 56 F.D.S. on 30 November 1944. We had heavy snow over Christmas, but pressure on the German lines continued although sometimes confined to patrols. Italian mulepack teams were used as a means of transport by the military in some areas.

One or two of us made treks into the mountains and in one hide-out I treated the the leader of an Italian partisan group, who had a bullet wound involving a kidney. For obvious reasons the partisan leader would not come to the F.D.S.

We joined No. 14 Indian Field Ambulance at Villa de Sassenero in March 1945. As we wound our way down a tortuous mountain pass our guns were firing as we passed underneath their muzzles and our 3-ton lorry seemed to be lifted up bodily and put down on the other side of the road like a feather as the guns fired.

General Harding (now Field-Marshal) visited us himself just before the final assault and from our positions we watched what proved to be the final barrage.

A tracheostomy performed on a soldier with multiple wounds around the face and neck because of acute respiratory embarrassment had a most gratifying result. The follow-up card stated that early primary suture had been possible and the patient was making a good recovery.

We moved forward very rapidly after the 14th April, crossing the Po on pontoon bridges. The banks of the river were piled high with German dead, many of whom I suppose must have been caught by shell-fire when trying to cross the river. By this time, and for some weeks beforehand, the Germans had been reduced to horse transport.

The Germans capitulated in Italy on the 2nd May. We were at Portogruaro on the 6th June when the War in Europe ended. The Germans had a C.C.S. here and the condition of their wounded was pitiful.

The intense interest in Field surgical work at that time, the good communications, the follow-up system and the overall supervision by Brigadiers Harold Edwards and Stammers ensured that we were kept well-informed about our patients. 
Mortality figures from penetrating wounds of the chest, thoraco-abdominal and penetrating wounds of the abdomen have already been mentioned. Thirteen other deaths from injuries to extremeties are known to me and are listed in Tables IV and V.

Table IV

Deaths in Forward Areas

\begin{tabular}{|c|c|c|c|c|}
\hline Case & Rank & Missile & Wounds & Death due to \\
\hline 1 & Sergeant & Mine & $\begin{array}{l}\text { Multiple amputation of both } \\
\text { wrists }\end{array}$ & Blast injury \\
\hline 2 & Private & Mine & $\begin{array}{l}\text { Multiple amputation through } \\
\text { both thighs }\end{array}$ & \\
\hline 3 & Sepoy & Mine & $\begin{array}{l}\text { Multiple amputation of right } \\
\text { upper limb }\end{array}$ & Gas gangrene \\
\hline 4 & Riffeman & Mine & $\begin{array}{l}\text { Multiple amputation through } \\
\text { right thigh }\end{array}$ & \\
\hline 5 & Fusilier & Mine & $\begin{array}{l}\text { Multiple amputation of right } \\
\text { lower leg }\end{array}$ & $\begin{array}{l}\text { Bronchopneumonia. } \\
\text { Blast injury }\end{array}$ \\
\hline 6 & P.O.W. & Machine gun & Multiple & Cardiac arrest \\
\hline 7 & Private & S. W. mortar & $\begin{array}{l}\text { Extensive left buttock and } \\
\text { perineum }\end{array}$ & Blast injury \\
\hline 8 & Fusilier & S.W. mortar & $\begin{array}{l}\text { Multiple amputation through } \\
\text { right thigh }\end{array}$ & \\
\hline 9 & Gunner & Shell & Multiple minor & Blast injury \\
\hline 10 & Captain & Bullet & Major head injury & $\begin{array}{l}\text { Cerebral } \\
\text { haemorrhage }\end{array}$ \\
\hline 11 & Italian boy & Grenade & Multiple major and minor & $\begin{array}{l}\text { Died suddenly } 1 \text { hour } \\
\text { post-operatively }\end{array}$ \\
\hline
\end{tabular}

Table V

Deaths after evacuation

\begin{tabular}{c|l|l|l|l}
\hline Case & \multicolumn{1}{|c|}{ Rank } & \multicolumn{1}{c|}{ Missile } & \multicolumn{1}{c|}{ Wounds } & \multicolumn{1}{c}{ Death due to } \\
\hline 12 & Rifleman & S.W. Mortar & $\begin{array}{l}\text { Perforated left external } \\
\text { iliac artery and vein }\end{array}$ & Gas gangrene \\
\hline 13 & Corporal & $\begin{array}{l}\text { Tank } \\
\text { accident }\end{array}$ & $\begin{array}{l}\text { Crushed pelvis. Ruptured } \\
\text { bladder }\end{array}$ & Crush syndrome \\
\hline
\end{tabular}

I am sure a few other patients died without my knowledge when we moved sometimes rapidly forward, or after patients had been evacuated, but I don't think there were many such deaths.

Wing-Commanders Brown and Binns (1970) recently described their experience in dealing with 776 casualties in Aden between 1964 and 1967, of which 120 died. Killed instantly were 54 and survived temporarily, but died without medical aid-38, which from my records seems to be about the same number of battle casualties as I had to treat in the twelve months from 1944 to 1945. 
The circumstances and logistics Brown and Binns (1970) encountered were very different. Armed tribesmen were in revolt in the mountains in the Radfan area 60 miles North of Aden, and British forces were virtually cut-off there except for air communications. There were casualties in Aden as well to be dealt with.

Views on the rates of resuscitation have changed as described by Brown and Binns (1970); the delay to operation in World War II was 4 to 5 hours usual, in Korea less than 3 hours advised, and in Aden and Viet-Nam $1 \frac{1}{2}$ to 2 hours. The average delay in operating on the patients with penetrating abdominal wounds in our hands was 9 hours from the time of wounding to operation, but the logistics were very different. The helicopter is responsible for a great deal of this improvement, but it throws increased emphasis on the need for high quality First Aid (Table 6).

Table VI

First Aid measures (Brown and Binns 1970)

\begin{tabular}{c|l|c|l}
\hline Priority & \multicolumn{1}{|c|}{ Measures } & Priority & \multicolumn{1}{|c}{ Measures } \\
\hline 1 & $\begin{array}{l}\text { Staunch catastrophic haemorrhage by } \\
\text { direct pressure (tourniquet) } \\
\text { Maintain clear airway, beware of } \\
\text { spinal cord }\end{array}$ & 3 & $\begin{array}{l}\text { Close sucking chest wound } \\
\text { Introduce intravenous plasma } \\
\text { Splint fracture(s) }\end{array}$ \\
\hline
\end{tabular}

Brown and Binns (1970) had very few failures and those they had were attributed to (a) Continued uncontrolled haemorrhage. (b) Massive peritoneal contamination, and (c) Blast injury to lungs or brain.

Lastly, they produced some interesting comparative mortality rates. For Aden 15.6 per cent, Cyprus 19.2 per cent, Viet-Nam 15 per cent and World War II 23 per cent. Their study is most important, illustrating what can be done when you have administrative medical control over the whole of a battle area with modern means of transport. They emphasise that all Service personnel should be taught First Aid.

Brown and Binns (1970) open their paper with the quotation "Nothing is new save that which has been forgotten." The lesson for a civilian surgeon is that "The organisation of accident services must be undertaken ... as a Quasi-military operation." (Capener 1970).

Accidents, civil disorders, explosions, missile injuries and burns today present surgeons with an increasingly wide variety of open and closed injuries. Admitted, as they often are, to general wards not specially set aside to deal with accidents, they are liable to cause confusion among medical officers and nursing staff trying to deal with routine work and other general surgical emergencies, and regretfully they may not always received the attention which they warrant.

Ideally these patients should be cared for in units specially set aside for them but for various reasons, geographical, historical or economic, this is not always possible. Until such time as Accident Units are more generally available, and even after that, it is important to realise how much can be done for these patients by application of general principles and some experience.

The danger is that the setting up of Intensive Care Units may result occasionally in an attitude of helplessness if for any reason a severely injured patient cannot be 
taken into such a unit. The higher grades of nursing staff tend to be absorbed by special units, increasing the difficulties of ensuring that the principles of intensive care should be carried out in the minds of those looking after surgical cases wherever they may be admitted and requiring first and foremost clinical alertness and awareness of what injuries may have been inflicted (London 1949, 1970).

The British Journal of Hospital Medicine produced an excellent Symposium on Shock (1968), Volume 1, Number 3. The pathogenesis and treatment of shock are much better established now (Davies and Davies 1968, Gruber 1970, Sevitt and Stoner 1970). Anaesthetists are often foremost in the management of this aspect, relieving surgeons of the intricacies of detail involved. However, the frequent changes of junior surgical and nursing staff require that the arrangements for handling these casualties should be reviewed regularly, not just in Special Units but throughout each hospital group.

At the heart of the problem is the desperate need to make Casualty posts attractive and Casualty Departments efficient in all respects, ensuring that an experienced officer is always available to decide priorities, institute appropriate first aid measures and arrange for the proper disposal of the patients thereafter.

A corollary to an efficient Casualty Department is that it should have the backing of a small group with executive power to put into action conclusions derived from regular study of the work of the Department itself, and of disasters elsewhere, and the medical consequences of rioting (Rutherford 1970).

The experience of the Department of Surgery in Belfast (Robb and Matthews 1971) serves to emphasise still further the essential need to have a Surgical Consultant to exercise authority in a Casualty Department.

\section{REFERENCES}

BRown, R. F. and BiNNs, J. H. (1970). Injury 1, 293.

CAPENER, N. (1970). Brit.J. Surg. 57, 769.

DAVIES, Joyce and DaVIES, I. S. T. (1968). Brit. J. hosp. Med. $2,686$.

EDWARDS, H. C. (1945). Proceedings of the Congress of C.M.F. Surgeons.

FIELD SURGerY POCKet Book, A. War Office, H.M.S.O. London.

GrANT, R. T. and ReEVE, E. B. (1951). Spec. Rep. Ser. med. Res. Coun (Lond.). No. 277.

GRUBER, U. F. (1970). Brit. J. hosp. Med. 4, 631.

Hopkinson, D. A. W. and WATts, J. C. (1963). Proc. roy. Soc. Med. 56, 461.

LoNDON, P. S. (1969). Proc. roy. Soc. Med. 62, 248.

LondoN, P. S. (1970). Brit. J. hosp. Med. 4, 460.

McLeAVE, H. (1964). A Time to Heal. The Life of Ian Aird, the Surgeon. Heinemann. London.

Peideleivre, R., and -Michon, R. (1958). Med. biol. Ill. 6, 225.

RUTHERFORD, W. H. (1970). Brit. J. hosp. Med. 4, 461 .

Robb, J. D. A. and MatThEWs, J. G. W., (1971). Brit. J. Surg. 58, 413.

SEvitT, S. and Stoner, H. B. (1970). J. clin. Path. 23. Supp. (Roy. Coll. Path.) 4

THORESBY, F. P. and WATTS, J. C. (1967). Brit. J. Surg. 54, 25

WAR SURGERY SuPPLEMENT No. 3. Ed. by G. G. TAYLOR. War Injuries of the Chest and Abdomen. Brit. J. Surg.

WATts. J. C. (1960). Ann. roy. Coll. Surg. Engl. 27, 125. 